\title{
Functional dichotomy of $\mathrm{A} 20$ in apoptotic and necrotic cell death
}

\author{
Peter STORZ ${ }^{\star 1}$, Heike DÖPPLER ${ }^{\star}$, Christiane FERRAN $\dagger$, Shane T. GREY $\dagger+$ and Alex TOKER ${ }^{\star}$ \\ *Department of Pathology, Beth Israel Deaconess Medical Center, Harvard Medical School, 330 Brookline Avenue, Boston, MA 02215, U.S.A., †'Immunobiology Research Center, \\ Beth Israel Deaconess Medical Center, Harvard Medical School, 330 Brookline Avenue, Boston, MA 02215, U.S.A., and $\ddagger$ Arthritis and Inflammation Program, Garvan Institute \\ of Medical Research, 384 Victoria Street, Sydney, NSW 2010, Australia
}

\begin{abstract}
ROS (reactive oxygen species) play important roles in the progression of a number of human pathologies. ROS promote cell death, but can also induce gene transcription. The transcription factor $\mathrm{NF}-\kappa \mathrm{B}$ (nuclear factor $\kappa \mathrm{B}$ ) plays a critical role in oxidative stress responses. One of the proteins regulated by NF- $\kappa \mathrm{B}$ is the zinc-finger protein A20. In TNF (tumour necrosis factor)- $\alpha$ signalling, NF- $\kappa$ B induction of A20 leads to increased cell survival. In the present paper, we show that in response to oxidative stress, A20 actually enhances cell death by necrosis, but not by apoptosis. Exposure of cells to ROS leads to the up-regulation of A20 which acts via a negative-feedback loop to block NF- $\kappa \mathrm{B}$ activation and cellular survival. Silencing of A20 by RNAi (RNA interference) increases both the induction of $\mathrm{NF}-\kappa \mathrm{B}$ and the subsequent survival
\end{abstract}

of cells exposed to high doses of oxidative stress, which, in untreated cells, promotes death by necrosis. Cells which express high basal levels of A20 are less protected from oxidative-stressinduced cell death when compared with cells with lower A20 expression. We also show that A20 regulates NF- $\kappa$ B by blocking the degradation of $\mathrm{I} \kappa \mathrm{B}$ (inhibitory protein $\kappa \mathrm{B}$ ) $\alpha$. These data highlight a novel role for A20 in oxidative stress responses by terminating NF- $\kappa \mathrm{B}$-dependent survival signalling and thus sensitizing cells to death by necrosis.

Key words: A20, apoptosis, necrosis, nuclear factor $\kappa \mathrm{B}(\mathrm{NF}-\kappa \mathrm{B})$, oxidative stress, reactive oxygen species (ROS).

\section{INTRODUCTION}

ROS (reactive oxygen species) are metabolic by-products produced during many physiological processes, and have been increasingly recognized as critical components in disease and stressrelated cellular injuries, such as neurodegenerative diseases, cancer and inflammation [1]. The continuous exposure of organisms to oxidative stress requires cellular responses to avoid deregulation or lethal damage of genes or cells [2]. Thus ROS can activate intracellular signalling pathways that promote repair responses and can therefore effectively increase cellular survival [1-3]. The signalling pathways which mediate these responses are not well defined [4]. However, several studies have shown that the inducible transcription factor NF- $\kappa \mathrm{B}$ (nuclear factor $\kappa \mathrm{B}$ ) plays an important role in mediating such protective responses [2]. Increased survival of cells exposed to oxidative stress has also been linked to the activation of $\mathrm{NF}-\kappa \mathrm{B}[5,6]$. However, there is little information concerning the signalling pathways that mediate NF- $\kappa$ B induction by oxidative stress, although it is known that these pathways are distinct from those induced by cytokines [7].

We recently described an oxidative stress-induced signalling pathway that leads to the activation of NF- $\kappa \mathrm{B}[5,8]$. In this pathway, the activation of the serine/threonine kinase PKD (protein kinase D) plays a central role in NF- $\kappa \mathrm{B}$ induction and cellular protection against ROS-induced cell death. This signalling pathway converges with other NF- $\kappa \mathrm{B}$ activation pathways at the level of the IKK (inhibitory protein $\kappa \mathrm{B}$ kinase) signalosome. One reason why the activation of NF- $\kappa$ B induced by oxidative stress has not been well defined so far is that it appears to be cell-typedependent [2,9]. Moreover, it is not known why some cell types respond to oxidative stress by induction of $\mathrm{NF}-\kappa \mathrm{B}$, whereas others do not [2,7]. A first step in understanding oxidative-stressmediated cell signalling is to identify the genes that are induced by ROS and to define their contribution in the induction of, or protection from, cell death.

The exact function of NF- $\kappa \mathrm{B}$ in the prevention or induction of cell death is not fully understood. Depending on the stimulus, $\mathrm{NF}-\kappa \mathrm{B}$ can promote either pro- or anti-survival signalling, and can induce both anti-apoptotic and anti-necrotic genes [10,11]. One of the genes induced by NF- $\kappa \mathrm{B}$ in response to many stimuli is the zinc-finger protein A20, which has been shown to protect from TNF (tumour necrosis factor)- $\alpha$-induced apoptosis, but can also function via a negative-feedback loop to block NF- $\kappa \mathrm{B}$ [10,12-14]. A20 protein levels are drastically increased upon LPS (lipopolysaccharide)-, phorbol-ester-, IL-1 (interleukin-1)or TNF- $\alpha$-stimulated NF- $\kappa$ B activation $[15,16]$. Furthermore, overexpression of A20 inhibits cell death induced by these stimuli, and A20-knockout mice are more susceptible to TNF$\alpha$-stimulated apoptotic cell death [14]. However, the role of A20 in oxidative-stress-mediated NF- $\kappa$ B-dependent responses has not been explored. We therefore evaluated whether A20 is induced by oxidative stress, and investigated its potential role in regulating cell death through $\mathrm{NF}-\kappa \mathrm{B}$. Our results reveal that A20 sensitizes cells to oxidative-stress-mediated cell death. We show that A20 blocks NF- $\kappa$ B in a negative-feedback loop leading to cell death by necrosis, a function which is distinct from its anti-apoptotic role in cytokine-induced apoptosis. Moreover, we show that A20-mediated inhibition of NF- $\kappa$ B sensitizes cells to additional exposure of cells to ROS. The net effect is a reduction in cellular survival such that cells that express low levels of A20 are more protected from oxidative-stress-induced death by necrosis.

Abbreviations used: BSO, buthionine-sulphoximine; CHX, cycloheximide; DAPI, 4,6-diamidino-2-phenylindole; $\beta$-gal, $\beta$-galactosidase; GST, glutathione S-transferase; $I_{\kappa} \mathrm{B}$, inhibitory protein $\kappa \mathrm{B}$; IKK, I $\mathrm{I}_{\mathrm{B}}$ kinase; IL-1, interleukin-1; NF- $\kappa \mathrm{B}$, nuclear factor $\kappa \mathrm{B}$; PARP, poly(ADP-ribose) polymerase; PKD, protein kinase D; ROS, reactive oxygen species; RNAi, RNA interference; RT, reverse transcriptase; TNF, tumour necrosis factor; TRAF, TNF-receptor-associated factor.

1 To whom correspondence should be addressed (email pstorz@bidmc.harvard.edu). 
We therefore propose a model in which the levels of A20 define the sensitivity of cells to ROS-induced death.

\section{EXPERIMENTAL}

\section{Cell culture, antibodies, reagents and expression plasmids}

All cell lines were purchased from A.T.C.C. (Manassas, VA, U.S.A.). HeLa cells stably expressing the NF- $\kappa \mathrm{B}$ and $\beta$-gal $(\beta$ galactosidase) reporter genes have been described in [5]. AntiPKD, anti-IKK $\gamma$ or anti-IKK $\alpha / \beta$ antibodies were from Santa Cruz Biotechnology (Santa Cruz, CA, U.S.A.), anti-A20 was from Oncogene (Boston, MA, U.S.A.), anti- $\beta$-actin was from Sigma (St. Louis, MO, U.S.A.), anti-Src was from Upstate Biotechnology (Lake Placid, NY, U.S.A.), anti-I $\kappa \mathrm{B} \alpha$ and anti-PARP [poly(ADP-ribose) polymerase] were from Cell Signaling Technology (Beverly, MA, U.S.A.), and anti-FLAG was from Sigma. Cycloheximide, DAPI (4,6-diamidino-2-phenylindole) and rhodamine-phalloidin were from Sigma. Pervanadate was prepared as described [5]. $\mathrm{H}_{2} \mathrm{O}_{2}(30 \%)$ was from Fisher Scientific (Pittsburgh, PA, U.S.A.), and recombinant human TNF- $\alpha$ was a gift from Dr H. Wajant (Department of Molecular Internal Medicine Medical Polyclinic, Julius-Maximilians Universität Würzburg, Germany). The cloning of expression vectors for PKD and PKD.Y463E have also been described in [5]. N-terminal FLAG-tagged human A20 was cloned in pcDNA4-TO using the following primer pair: 5'-GCGGAATTCATGGACTATAAGGACGATGATGACAAAATGGCTGAACAAGTCCTTCCT-3' and 5'-GCGCTCGAGTTAGCCATACATCTGCTTGAACTG-3'. All constructs were verified by DNA sequencing. Other expression plasmids were generously provided by Dr B. Schaffhaussen (Biochemistry, Tufts University School of Medicine, Boston, MA, U.S.A.) (Src.Y527F), Dr T. Maniatis (Department of Molecular and Cellular Biology, Harvard University, Boston, MA, U.S.A.) [super-dominant $\mathrm{I} \kappa \mathrm{B} \alpha$, GST (glutathione S-transferase)- $\mathrm{I} \kappa \mathrm{B} \alpha$ ] and Dr V. M. Dixit (Molecular Oncology Department, Genentech Inc., South San Francisco, CA, U.S.A.) (non-tagged A20). Superfect (Qiagen, Valencia, CA, U.S.A.) or TransIT HeLa Monster (Mirus, Madison, WI, U.S.A.) were used for transient transfections of HeLa cells, according to the manufacturers' instructions. MDA-MB-435 cells were transfected using the AMAXA Nucleofector (AMAXA Biosystems, Köln, Germany).

\section{Immunoblotting and immunoprecipitation}

Cells were lysed in lysis buffer [50 mM Tris/HCl, $\mathrm{pH} 7.4,1 \%$ (v/v) Triton $\mathrm{X}-100,150 \mathrm{mM} \mathrm{NaCl}$ and $5 \mathrm{mM}$ EDTA] plus protease inhibitor cocktail (Sigma), and either lysates were used for immunoblot analysis or proteins of interest were immunoprecipitated by a $1 \mathrm{~h}$ incubation with the respective antibody $(2 \mu \mathrm{g})$, followed by a $30 \mathrm{~min}$ incubation with Protein $\mathrm{A} / \mathrm{G}-$ agarose (Santa Cruz Biotechnology). Immune complexes were washed three times with TBS $(50 \mathrm{mM}$ Tris/ $\mathrm{HCl}, \mathrm{pH} 7.4$, and $150 \mathrm{mM} \mathrm{NaCl})$, and resolved by SDS/PAGE (10\% gels).

\section{IKK protein kinase assays}

A $20 \mu \mathrm{l}$ volume of kinase buffer $(50 \mathrm{mM}$ Tris/HCl, $\mathrm{pH} 7.4$, $10 \mathrm{mM} \mathrm{MgCl}_{2}$ and $2 \mathrm{mM}$ dithiothreitol) was added to IKK $\gamma$ immunoprecipitates, and the reaction was carried out for $30 \mathrm{~min}$ by addition of $10 \mu \mathrm{l}$ of kinase mixture ( $4 \mu \mathrm{g}$ of GST-I $\kappa \mathrm{B} \alpha$ amino acids 5-55, $50 \mu \mathrm{M}$ ATP and $10 \mu \mathrm{Ci}$ of $\left[\gamma-{ }^{32} \mathrm{P}\right] \mathrm{ATP}$ in kinase buffer). To terminate, $30 \mu 1$ of $2 \times$ SDS sample buffer was added, and the samples were resolved by SDS/PAGE (10\% gels). The gels were dried and analysed on a Molecular Imager (Bio-Rad, Hercules, CA, U.S.A.).

\section{RNAi (RNA interference)}

To transiently silence the expression of A20, the following oligonucleotides were cloned into the pSuper vector [17]: 5'-GATCCCCCCATGCACCGATACACACTTTCAAGAGAAGTGTGTATCGGTGCATGGTTTTTGGAAA-3' and 5'-AGCTTTTCCAAAAACCATGCACCGATACACACTTCTCTTGAAAGTGTGTATCGGTGCATGGGGG-3' (A20 RNAi Seq.1) or 5'-GATCCCCCGGTGACGGCAATTGCCTCTTCAAGAGAGAGGCAATTGCCGTCACCGTTTTTGGAAA-3' and 5'-AGCTTTTCCAAAAACGGTGACGGCAATTGCCTCTCTCTTGAAGAGGCAATTGCCGTCACCGGGG-3' (A20 RNAi Seq.2). HeLa cells were transfected with pSuper-A20 RNAi using the TransIT HeLa Monster transfection reagent. In all experiments, the cells were transfected at $30 \%$ confluence. Transfection efficiencies (95-100\%) were controlled using a GFP (green fluorescent protein) expression vector. Experiments were performed as indicated 48, 72 or $96 \mathrm{~h}$ after initial transfection. Reduced expression of A20 was evaluated by RT (reverse transcriptase)-PCR or immunoblotting.

\section{RT-PCR}

Cellular mRNA isolation was performed using RNA-Bee (TELTEST, Friendswood, TX, U.S.A.), according to the manufacturer's instructions, and mRNA was transcribed into cDNA using Superscript II (Invitrogen, Carlsbad, CA, U.S.A.). For the transcription reaction, $1 \mu \mathrm{g}$ of OligodT(18) primer (New England Biolabs, Beverly, MA, U.S.A.) and $1 \mu \mathrm{g}$ of RNA were incubated in a total volume of $10 \mu \mathrm{l}$ of water at $70^{\circ} \mathrm{C}$ for $10 \mathrm{~min}$. Then, $5 \times$ buffer, 40 units of RNasin (Roche, Mannheim, Germany), $200 \mu \mathrm{M}$ dNTPs (New England Biolabs), $10 \mathrm{mM}$ dithiothreitol and 300 units of Superscript II reverse transcriptase were added to a total volume of $20 \mu \mathrm{l}$. The reaction was carried out at $45^{\circ} \mathrm{C}$ for $60 \mathrm{~min}$, and then heat-inactivated at $95^{\circ} \mathrm{C}$ for $5 \mathrm{~min}$. The resulting cDNA pool was subjected to PCR analysis using the following primers for $\mathrm{A} 20$ and $\beta$-actin: human A20 oligonucleotides (product size $410 \mathrm{bp}$ ), 5'-CGCTCAAGGAAACAGACACA-3' and 5'-CTTCAGGGTCACCAAGGGTA-3'; and human $\beta$-actin oligonucleotides (product size $620 \mathrm{bp}$ ), 5'-CCTCGCCTTTGCCGATCC-3' and 5'-GGATCTTCATGAGGTAGTCAGTC-3'. Reaction conditions for the PCR were $1 \mathrm{~min}$ of annealing at $55^{\circ} \mathrm{C}$ and $1 \mathrm{~min}$ of amplification at $72^{\circ} \mathrm{C}$, with 30 cycles (for A20) and 20 cycles for $\beta$-actin.

\section{Reporter gene assays}

Cells were transiently co-transfected with a NF- $\kappa$ B-reporter construct (NF- $\kappa \mathrm{B}-\mathrm{luc}, 5 \mu \mathrm{g}), 1 \mu \mathrm{g}$ of pCS2-(n) $\beta$-gal and the cDNA of interest $(1 \mu \mathrm{g})$ using Superfect. Assays for luciferase and $\beta$-gal activity were performed on total cell lysates using standard assays, and were measured on a luminometer. Luciferase activity was normalized to the $\beta$-gal activity. Protein expression was controlled by immunoblot analysis.

\section{DAPI and phalloidin staining}

Cells were seeded on coverslips in cell culture dishes (MatTek Corporation, Ashland, MA, U.S.A.). After stimulation, the cells were rinsed once with PBS, fixed with $3.5 \%$ (w/v) paraformaldehyde in PBS for $10 \mathrm{~min}$ at $37^{\circ} \mathrm{C}$, rinsed once with PBS and once with DAPI buffer $(100 \mathrm{mM} \mathrm{NaCl}, 10 \mathrm{mM}$ EDTA and $10 \mathrm{mM}$ Tris/ $\mathrm{HCl}, \mathrm{pH} 7.0)$ and stained for $1 \mathrm{~h}$ at $37^{\circ} \mathrm{C}$ with DAPI $(0.1 \mu \mathrm{g} / \mathrm{ml})$ in DAPI buffer. After the DAPI staining, the coverslips were rinsed three times with DAPI buffer and once with PBS. PBS was removed and $30 \mu \mathrm{l}$ of phalloidin (stock of 
$100 \mu \mathrm{g} / 200 \mu \mathrm{l}$ of methanol was diluted 1:200 in PBS) was added directly to the cells for $15 \mathrm{~min}$ at room temperature $\left(20^{\circ} \mathrm{C}\right)$. Cells were rinsed three times with PBS and photographed in PBS.

\section{Flow cytometric analysis of cellular DNA content}

Cells were seeded and stimulated as indicated. The detached cells were collected, and adherent cells were harvested ( 5 min of incubation with $0.25 \%$ trypsin and $1 \mathrm{mM}$ EDTA). Cells were washed with PBS containing $2 \%$ foetal calf serum $\left(4^{\circ} \mathrm{C}\right)$. Cell numbers were adjusted to $10^{6}$ per $\mathrm{ml}$. Ice-cold ethanol $(3 \mathrm{ml})$ was added to $1 \mathrm{ml}$ of cell suspension, and the suspension was vortex-mixed. The cells were stored overnight at $4^{\circ} \mathrm{C}$, and were washed twice with PBS and stained for $3 \mathrm{~h}$ at $4^{\circ} \mathrm{C}$ with $1 \mathrm{ml}$ of PI (propidium iodide) solution $(50 \mu \mathrm{g} / \mathrm{ml}$ propidium iodide and $3.8 \mathrm{mM}$ sodium citrate, $50 \mu \mathrm{g} / \mathrm{ml}$ ). Cells were washed once with $3.8 \mathrm{mM}$ sodium acetate, and analysed by flow cytometry.

\section{Cell viability and cell survival assays}

Cells were transfected as indicated, and, after $24 \mathrm{~h}$, were seeded in 96-well plates in cell culture medium. After the indicated times, or after $24 \mathrm{~h}$ (standard assay), cells were treated with $\mathrm{H}_{2} \mathrm{O}_{2}$ or TNF$\alpha / \mathrm{CHX}$ (cycloheximide) for $16 \mathrm{~h}$. Cells were washed twice with PBS and stained for 15 min with a Crystal Violet solution $(0.5 \%$ Crystal Violet in $20 \%$ methanol). Plates were rinsed and dried. The dye was dissolved in methanol and the $D_{550}$ was measured on an ELISA plate reader $[18,19]$.

\section{RESULTS}

\section{A20 expression levels sensitize cells to oxidative stress}

We compared the expression levels of A20 in several different cell lines (Figure 1A). We observed a high constitutive expression of both A20 mRNA and protein levels in the human colon carcinoma cell line Clone $\mathrm{A}$, as well as in the human breast carcinoma cell line MDA-MB-435. Conversely, both HeLa cells and HEK293 (human embryonic kidney) cells had lower levels of A20 (Figure 1A). Since A20 has been described as a protein that protects cells from apoptosis induced by various stimuli $[13,14]$, we analysed its role in oxidative-stress-mediated cell death. We evaluated the ability of oxidative stress to induce death in HeLa cells compared with Clone A and MDA-MB-435 cells. Surprisingly, MDA-MB-435 cells, which contain the highest A20 levels, were significantly more sensitive to $\mathrm{H}_{2} \mathrm{O}_{2}$-induced cell death compared with Clone A and HeLa cells. HeLa cells were the least sensitive to $\mathrm{H}_{2} \mathrm{O}_{2}$, and this correlated with the lowest expression levels of A20 (Figure 1B). Taken together, A20 expression levels in three different cell lines correlated with their sensitivity to oxidative-stress-mediated cell death induced by $\mathrm{H}_{2} \mathrm{O}_{2}$. This correlation was addressed more directly by silencing or by overexpression of A20 in MDA-MB-435 cells (high expression of A20) and HeLa cells (low expression of A20), and subsequent analysis of its effects on cellular survival. Exposure of A20 RNAi-transfected MDA-MB-435 cells to increasing doses of $\mathrm{H}_{2} \mathrm{O}_{2}$ significantly decreased their sensitivity to $\mathrm{H}_{2} \mathrm{O}_{2}$, such that control transfected cells were less protected against $\mathrm{H}_{2} \mathrm{O}_{2}$-induced death compared with their A20 RNAi-expressing counterparts (Figure 1C).

\section{Opposing effects of A20 in oxidative-stress- and TNF- $\alpha$-mediated cell death}

To investigate this further, HeLa cells (which express low endogenous levels of A20) were transfected with a FLAG-tagged A20 allele, and were exposed to TNF- $\alpha$ and $\mathrm{H}_{2} \mathrm{O}_{2}$, stimuli which induce
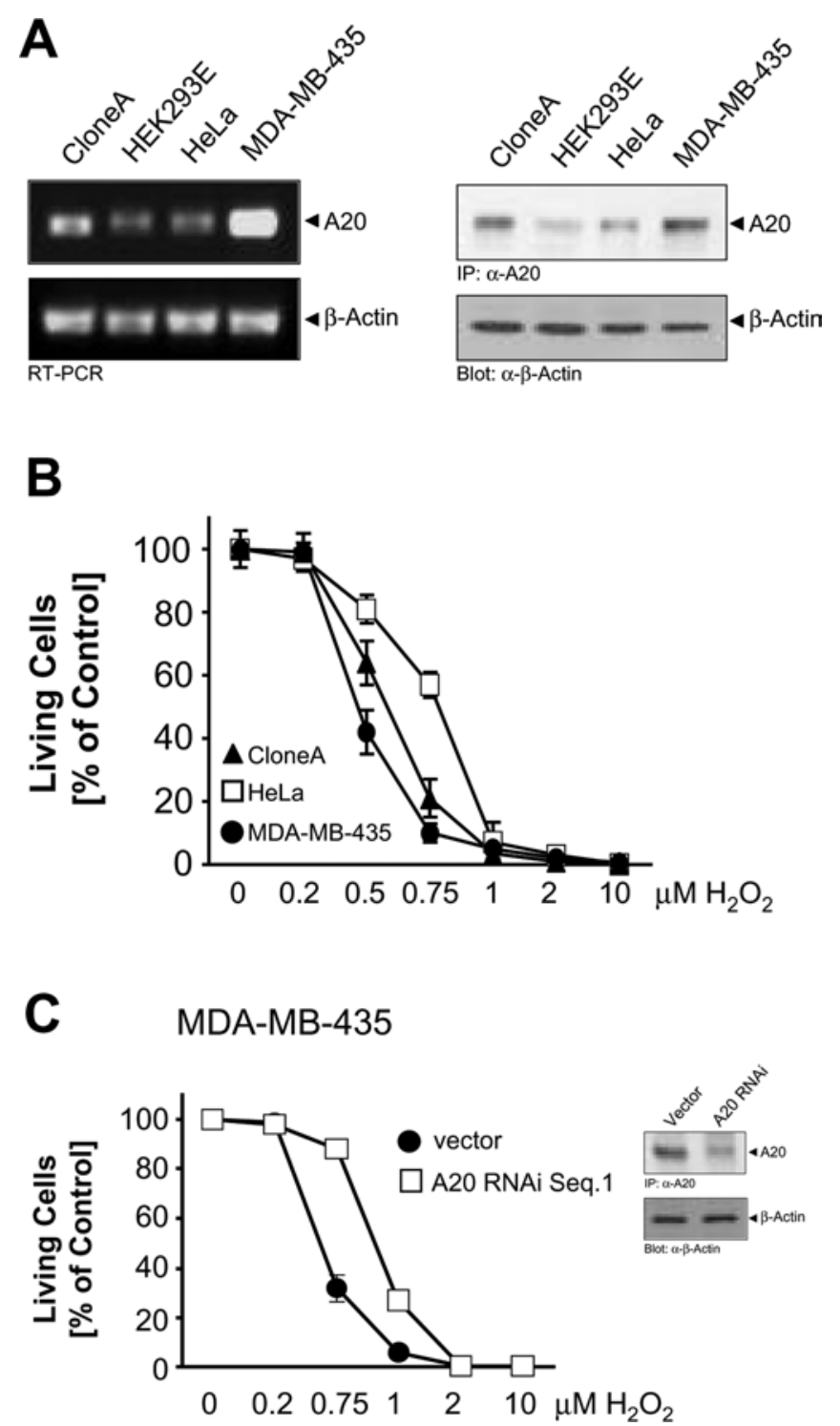

Figure 1 Cells which express high basal levels of A20 are less protected against $\mathrm{H}_{2} \mathrm{O}_{2}$-induced death

(A) RNA was isolated from the indicated cell lines and RT-PCR was performed for A20 and $\beta$-actin, or A20 was immunoprecipitated and revealed by immunoblotting with anti-A20 ( $\alpha$-A20). Immunoblots for $\beta$-actin ( $\alpha$ - $\beta$-actin) served as a control. (B) HeLa cells ( $\square$ ), Clone A cells $(\boldsymbol{\Lambda})$ and MDA-MB-435 cells $\left(-\right.$ ) were treated with the indicated doses of $\mathrm{H}_{2} \mathrm{O}_{2}$ for $16 \mathrm{~h}$. Living cells were counted by Crystal Violet staining. Results are means \pm S.D. (C) MDA-MB- 435 cells transfected with control pSUPER $(\square)$ or transfected with pSUPER.A20 RNAi for $48 \mathrm{~h}(\bullet)$ were treated with the indicated doses of $\mathrm{H}_{2} \mathrm{O}_{2}$ for $16 \mathrm{~h}$. Cell viability was determined by Crystal Violet staining. Results are means \pm S.D. Inset, A20 was immunoprecipitated and revealed by immunoblotting with anti-A20 $(\alpha-\mathrm{A} 20)$. Immunoblots for $\beta$-actin $(\alpha-\beta$-actin) served as a control.

cell death. Interestingly, A20 expression enhanced cell death induced by oxidative stress (Figure 2A). Conversely, transient expression of A20 increased cellular survival from death by apoptosis induced by TNF- $\alpha / \mathrm{CHX}$ (Figure 2A). Therefore, despite its anti-apoptotic function in cytokine signalling, A20 actually enhances death when cells are exposed to oxidative stress. To substantiate this finding further, we also used A20 RNAi to reduce $\mathrm{A} 20$ expression and investigate the consequence for $\mathrm{H}_{2} \mathrm{O}_{2}$-induced death. Two distinct A20 RNAi sequences blocked $\mathrm{H}_{2} \mathrm{O}_{2}$ stimulated induction of A20 mRNA and protein (Figure $2 \mathrm{~B}$ ) and 
A

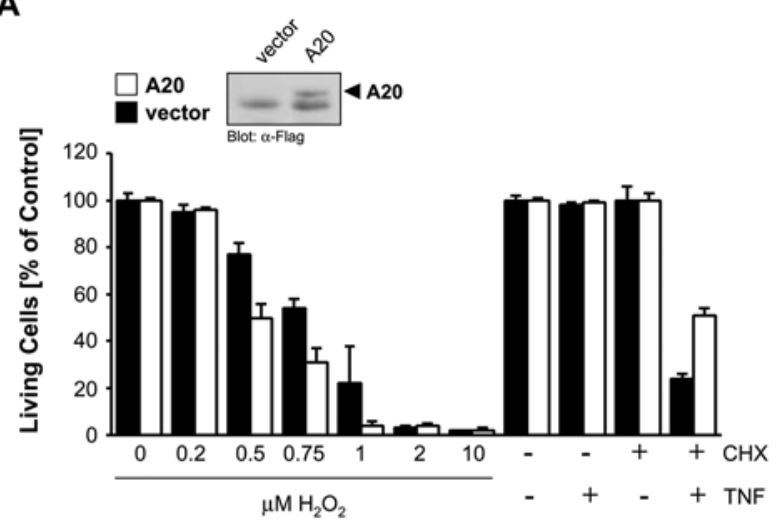

B

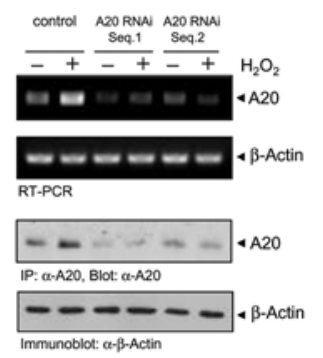

C

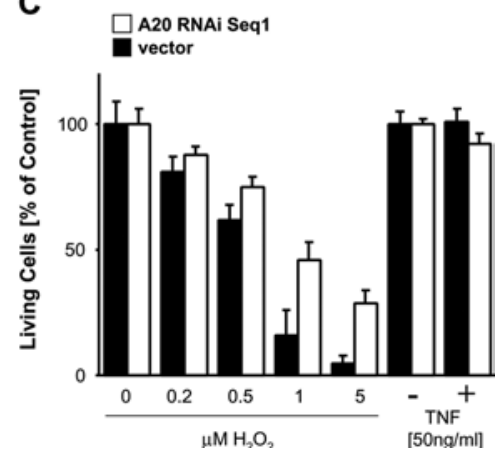

Figure 2 A20 sensitizes cells to oxidative-stress-mediated cell death

(A) HeLa cells were transfected with A20 (open bars) or vector control (closed bars). At $48 \mathrm{~h}$ after transfection, cells were treated with $\mathrm{H}_{2} \mathrm{O}_{2}$ or TNF- $\alpha(50 \mathrm{ng} / \mathrm{ml}) / \mathrm{CHX}(1 \mu \mathrm{g} / \mathrm{ml})$ as indicated for $16 \mathrm{~h}$. Living cells were analysed by Crystal Violet staining. Results are means + S.D. A2O expression was shown by immunoblotting ( $\alpha$-FLAG, the lower band is non-specific). (B) HeLa cells were transfected with vector control (pSuper) or A20 RNAi (pSuper.A20 RNAi Seq.1 or Seq.2) for $48 \mathrm{~h}$, and were then treated with $\mathrm{H}_{2} \mathrm{O}_{2}(500 \mathrm{nM}, 4 \mathrm{~h}$ ). A20 was immunoprecipitated and immunoblotted $(\alpha$-A20) or RNA was isolated and RT-PCR was performed. $\beta$-Actin expression served as a control (immunoblot: $\alpha$ - $\beta$-actin, or RT-PCR). (C) HeLa cells were transfected with vector control (pSuper, closed bars) or A20 RNAi (pSuper.A20 RNAi Seq.1, open bars) for $48 \mathrm{~h}$, and were then treated with increasing concentrations of $\mathrm{H}_{2} \mathrm{O}_{2}$ or with TNF- $\alpha$, as indicated. Living cells were analysed by Crystal Violet staining. Results are means \pm S.D.

cells transfected with A20 RNAi were more protected against $\mathrm{H}_{2} \mathrm{O}_{2}$-induced death than control transfected cells (Figure 2C).

To induce TNF-mediated cell death, protein synthesis of protective genes such as those induced by $\mathrm{NF}-\kappa \mathrm{B}$ is effectively blocked by $\mathrm{CHX}$ [19]. A20 overexpression did not fully protect cells from TNF/CHX-mediated cell death (Figure 2A), indicating that TNF also induces the synthesis of other protective proteins. Also, the specific block of A20 induction by A20 RNAi did not result in cell death in response to TNF, as would be expected if A20 is the only protective protein induced by TNF (Figure 2C).

\section{Oxidative stress promotes cell death by necrosis}

We next analysed if the cell death induced by oxidative stress is mediated by apoptosis. A dose-dependent exposure of HeLa and other cell lines to oxidative stress revealed that $\mathrm{H}_{2} \mathrm{O}_{2}$ concentrations of $1 \mu \mathrm{M}$ or higher induced cell death (Figures 1B and 3A). We extended our observations in HeLa cells, where $\mathrm{H}_{2} \mathrm{O}_{2}$ concentrations of $1 \mu \mathrm{M}$ or higher induce cell death, whereas $\mathrm{H}_{2} \mathrm{O}_{2}$ concentrations of $500 \mathrm{nM}$ or lower did not. HeLa cells exposed to high doses of $\mathrm{H}_{2} \mathrm{O}_{2}$ showed a typical necrotic morphology with intact nuclei and their actin organized into retraction fibres (Figure $3 \mathrm{~B})$. These cells did not undergo apoptosis, since they did not show any evidence of chromatin condensation (Figure 3B) or DNA fragmentation (Figure 3C). Cells exposed to low concentrations of $\mathrm{H}_{2} \mathrm{O}_{2}$ showed slight increases in the size of nuclei, more organized actin structures (Figure $3 \mathrm{~B}$ ) and revealed a pattern of cellular DNA content comparable with untreated cells (Figure 3C). We also evaluated caspase-mediated PARP cleavage, one hallmark in the induction of apoptotic cell death, in response to $\mathrm{H}_{2} \mathrm{O}_{2}$ (Figure 3D). The lack of PARP cleavage in all cells treated with $\mathrm{H}_{2} \mathrm{O}_{2}$ (Figure 3D), together with the lack of chromatin condensation (DAPI staining; Figure 3B) and DNA fragmentation (Figure 3C) shows that, in these cells, $\mathrm{H}_{2} \mathrm{O}_{2}$ does not induce death by apoptosis, but rather by necrosis.

\section{Inhibition of NF- $\kappa$ B sensitizes cells to necrotic cell death}

A20 has been shown to be induced by $\mathrm{NF}-\kappa \mathrm{B}$ in response to many stimuli, and has also been shown to protect cells from TNF$\alpha$-induced apoptosis [13,14]. Moreover, previous studies have revealed that A20 can function in a negative-feedback loop to block activation of $\mathrm{NF}-\kappa \mathrm{B}$ and downstream responses [15,20,21]. We therefore examined the role of A20 in NF- $\kappa$ B-dependent responses in oxidative stress signalling. First, we confirmed that exposure of HeLa cells to oxidative stress $\left(\mathrm{H}_{2} \mathrm{O}_{2}\right)$ leads to NF- $\kappa \mathrm{B}$ activation (Figure 4A), consistent with numerous previous studies. Next, since it has been shown that $\mathrm{NF}-\kappa \mathrm{B}$ can promote pro-survival signalling [11], we evaluated cell death in cells in which $\mathrm{NF}-\kappa \mathrm{B}$ activation is blocked. Cells expressing a super-dominant $\mathrm{I} \kappa \mathrm{B} \alpha$ were exposed to increasing concentrations of oxidative stress, and this treatment led to a marked increase in cell death, when compared with control cells (Figure 4B). Therefore oxidative-stress-induced cell death is potentiated by blocking NF- $\kappa \mathrm{B}$ activation.

Oxidative stress, generated either by $\mathrm{H}_{2} \mathrm{O}_{2}$ or by compounds which elevate intracellular ROS, such as pervanadate or BSO (buthionine-sulphoximine), which causes the depletion of glutathione, the major intracellular ROS scavenger [22,23], up-regulated A20 mRNA and protein levels, comparable with the positive control TNF- $\alpha$ (Figure 5A). We have shown previously that the oxidative-stress-induced signalling pathway that mediates NF- $\kappa \mathrm{B}$ activation and cellular survival in HeLa cells requires the tyrosine kinase $\mathrm{Src}$ and the serine/threonine kinase PKD [5,24,25]. Interestingly, expression of active alleles of both Src and PKD (Src.Y527F and PKD.Y463E respectively) also increased A20 mRNA and protein levels, demonstrating that NF- $\kappa$ B induction of A20 by oxidative stress can be mediated via the Src-PKD pathway (Figure 5B).

\section{A20 expression blocks NF- $\kappa$ B activation}

To determine whether induction of $\mathrm{A} 20$ by NF- $\kappa$ B can blunt the oxidative-stress-mediated NF- $\kappa \mathrm{B}$ activation pathway, we measured the ability of HeLa cells transfected with A20 to induce $\mathrm{NF}-\kappa \mathrm{B}$ in response to $\mathrm{H}_{2} \mathrm{O}_{2}$. NF- $\kappa \mathrm{B}$ transcriptional activity induced by $\mathrm{H}_{2} \mathrm{O}_{2}$, pervanadate, TNF- $\alpha$, activated Src (Src.Y527F) and activated PKD (PKD.Y463E) was significantly blunted in cells transiently transfected with A20 (Figure 6). This suggests that the induction of $\mathrm{A} 20$ by oxidative stress initiates a negativefeedback loop which blocks NF- $\kappa$ B. This was confirmed using A20 RNAi, which significantly increased NF $-\kappa \mathrm{B}$ reporter activity in cells exposed to oxidative stress (Figure 7A) or TNF- $\alpha$ (Figure 7B). As expected, A20 RNAi also blocked induction of A20 protein induced by $\mathrm{H}_{2} \mathrm{O}_{2}$ and TNF- $\alpha$ (Figure 7C). Therefore A20 acts as a negative regulator of $\mathrm{NF}-\kappa \mathrm{B}$ in response to oxidative stress. 
A
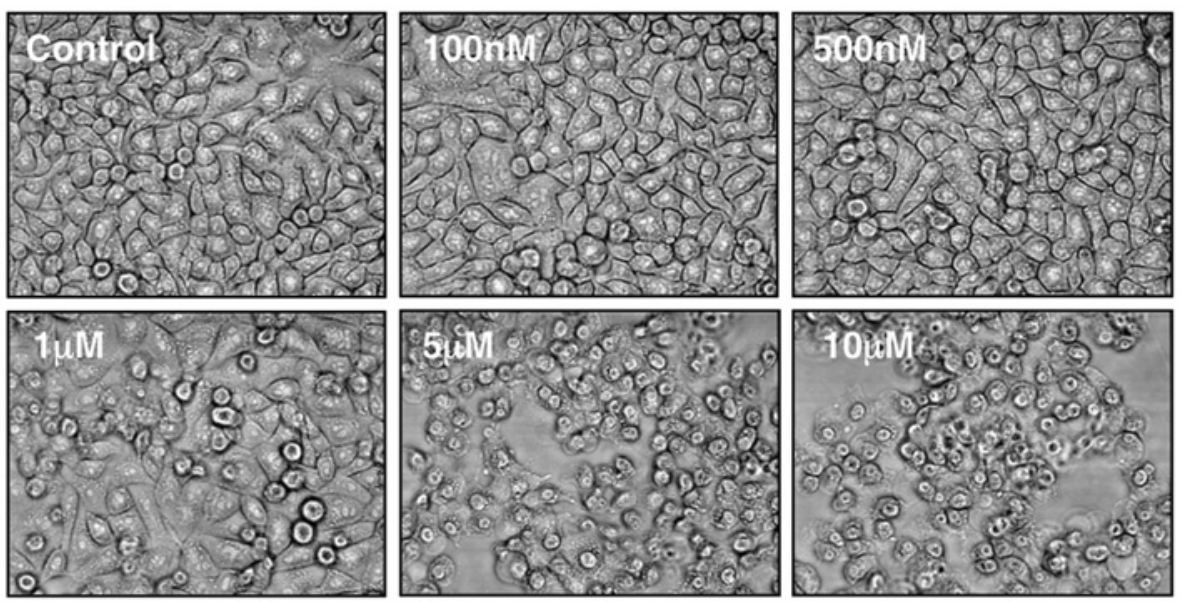

B
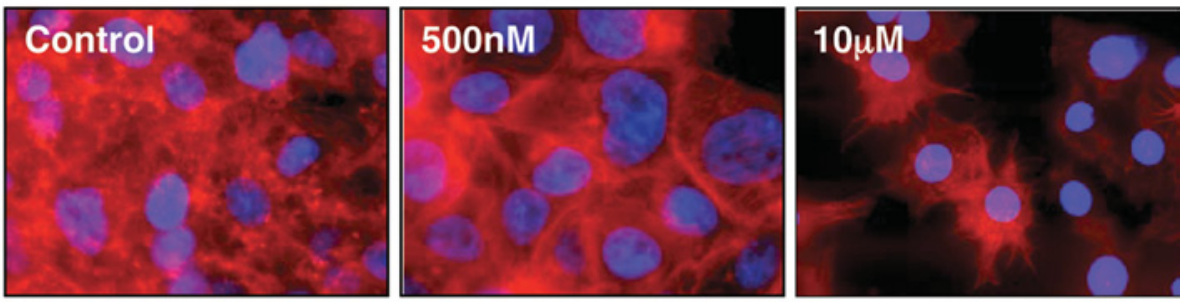

C

Control

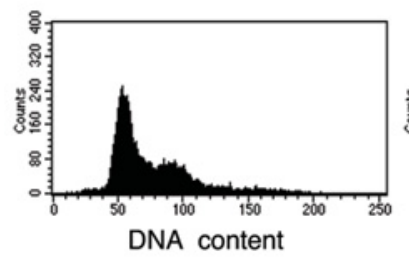

D

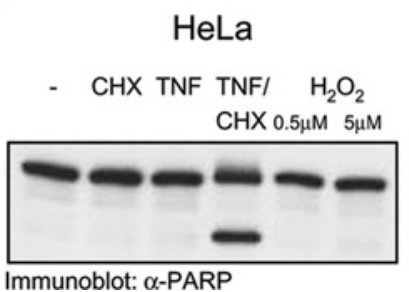

$$
\mathrm{H}_{2} \mathrm{O}_{2}(500 \mathrm{nM})
$$

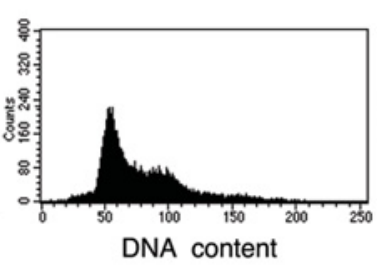

MDA-MB 435

\section{HEK293E}

$\mathrm{H}_{2} \mathrm{O}_{2}$ $0.5 \mu \mathrm{M} 5 \mu \mathrm{M}$

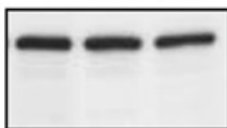

$\mathrm{H}_{2} \mathrm{O}_{2}(10 \mu \mathrm{M})$

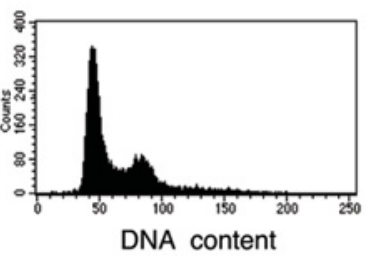

Figure 3 Oxidative stress induces death by necrosis and not by apoptosis

(A) HeLa cells were treated with $\mathrm{H}_{2} \mathrm{O}_{2}\left(16 \mathrm{~h}\right.$ ) as indicated, and photographed (phase-contrast, 10x magnification). (B) HeLa cells were treated with $\mathrm{H}_{2} \mathrm{O}_{2}(16 \mathrm{~h})$ as indicated. Nuclei and F-actin were stained with DAPI (nuclei) and rhodamine-phalloidin (F-actin) ( $40 \times$ magnification). (C) HeLa cells were treated with $\mathrm{H}_{2} \mathrm{O}_{2}(16 \mathrm{~h})$ as indicated, and the DNA content was determined by flow cytometry. (D) Cells were treated for $4 \mathrm{~h}$ with $\mathrm{H}_{2} \mathrm{O}_{2}$ as indicated. TNF- $\alpha(50 \mathrm{ng} / \mathrm{ml}, 4 \mathrm{~h}) / \mathrm{CHX}(1 \mu \mathrm{g} / \mathrm{ml}, 5 \mathrm{~h})$ was used as a control for PARP cleavage. PARP cleavage was detected by immunoblotting with anti-PARP ( $\alpha$-PARP). Full-length PARP and the cleaved fragment are indicated with arrows.

In HeLa cells, oxidative-stress-dependent $\mathrm{NF}-\kappa \mathrm{B}$ activation converges with other NF- $\kappa$ B activation cascades at the level of the I $\kappa$ B-IKK signalling complex [5,26,27]. Moreover, A20 blocks NF- $\kappa$ B activation mediated by a constitutively active PKD allele (PKD.Y463E), suggesting that A20 functions either downstream, or at the same level, as PKD (Figure 6D). Although PKD is associated with the IKK complex in response to oxidative stress [5], co-expression of PKD with A20 does not block the ability of PKD to translocate to IKK in $\mathrm{H}_{2} \mathrm{O}_{2}$-stimulated cells (results not shown). However, the expression of A20 blocks 
A

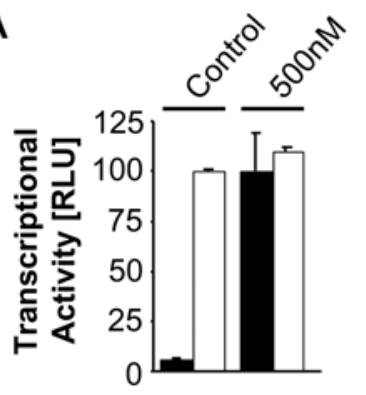

B

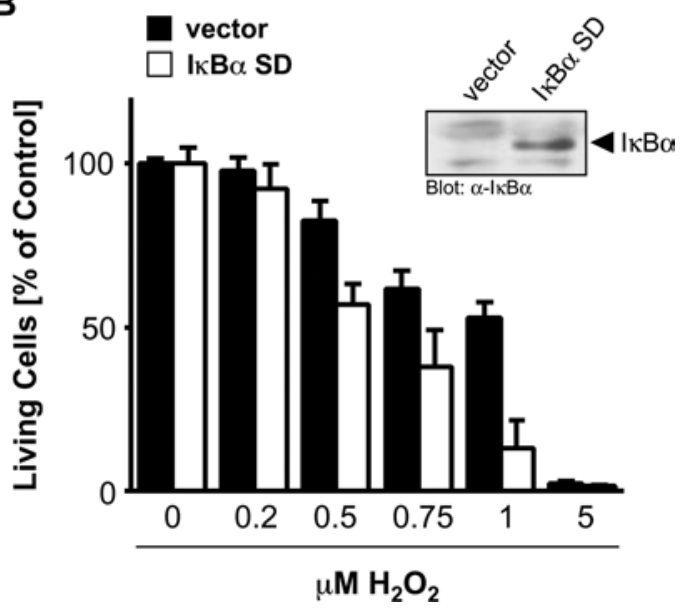

Figure $4 \mathrm{NF}-\kappa \mathrm{B}$ activation protects cells from oxidative-stress-induced death

(A) HeLa cells were transfected with reporter constructs, and, $8 \mathrm{~h}$ after transfection, were stimulated with $\mathrm{H}_{2} \mathrm{O}_{2}$ ( $500 \mathrm{nM}, 16 \mathrm{~h}$ ). Reporter gene assays were performed to measure inducible NF- $\kappa$ B transcriptional activity (NF- $\kappa$ B-luc reporter plasmid, closed bars) or general transcriptional activity ( $\beta$-gal reporter plasmid, open bars). Results are means \pm S.D. RLU, relative light units. (B) HeLa cells were transfected with vector control or super-dominant $I_{\kappa} \mathrm{B} \alpha\left(\left.\right|_{\kappa} \mathrm{B} \alpha \mathrm{SD}\right)$. After $48 \mathrm{~h}$, cells were treated with $\mathrm{H}_{2} \mathrm{O}_{2}(16 \mathrm{~h})$ as indicated, and living cells were determined by Crystal Violet staining. Results are means \pm S.D. Inset, lysates of control and $I_{\kappa} B \alpha$-transfected cells were analysed for $I_{\kappa} B \alpha$ expression by immunoblotting with anti- $I_{\kappa} B \alpha$.

oxidative-stress-mediated $\mathrm{I} \kappa \mathrm{B} \alpha$ degradation, which translates into a block in NF- $\kappa$ B activation (Figure 8).

\section{A20 sensitizes cells to oxidative-stress-induced cell death}

The above data suggest that, by regulating the levels of A20, NF$\kappa \mathrm{B}$ may control the balance between necrotic cell death and cellular survival in response to oxidative stress. To test this model, we pre-treated $\mathrm{HeLa}$ cells with $500 \mathrm{nM} \mathrm{H}_{2} \mathrm{O}_{2}$ for $8 \mathrm{~h}$ (maximal induction of NF- $\kappa$ B which also up-regulates A20, but does not promote cell death [5]), and then re-exposed the same cells to increasing concentrations of oxidative stress (for $16 \mathrm{~h}$ ). Under these conditions, cells were sensitized to $\mathrm{H}_{2} \mathrm{O}_{2}$ doses (e.g. $250 \mathrm{nM}$ ) which, under normal conditions, do not induce cell death when compared with control cells (Figure 9A). Furthermore, as predicted, activation of IKK was blocked in cells which were pretreated with $\mathrm{H}_{2} \mathrm{O}_{2}$ (Figure 9B, compare with Figure 7C). Control cells which were not pre-treated with $\mathrm{H}_{2} \mathrm{O}_{2}$ showed a normal IKK response. These data suggest that the induction of $\mathrm{A} 20$ observed in response to $\mathrm{H}_{2} \mathrm{O}_{2}$ blocks NF- $\kappa$ B such that the re-exposure of
A

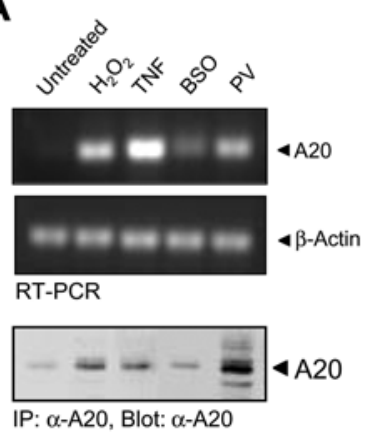

B

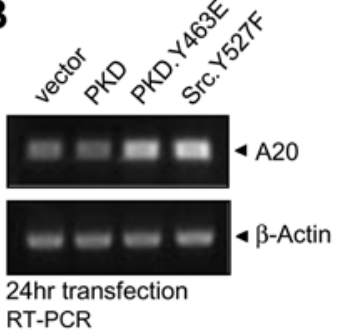

RT-PCR

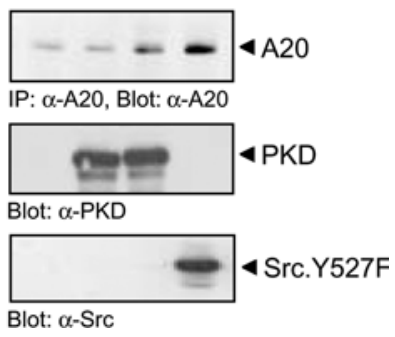

Figure 5 0xidative stress induces A20 expression

HeLa cells were stimulated ( $4 \mathrm{~h}$ for RT-PCR or $8 \mathrm{~h}$ for protein analysis) with $\mathrm{H}_{2} \mathrm{O}_{2}(500 \mathrm{nM})$, pervanadate $(75 \mu \mathrm{M}), \mathrm{BSO}(100 \mu \mathrm{M})$ or TNF- $\alpha(50 \mathrm{ng} / \mathrm{ml})(\mathbf{A})$ or cells were transfected $(24 \mathrm{~h})$ with wild-type PKD (PKD), constitutively active PKD (PKD.Y463E) or active Src (Src.Y527F) (B). A20 mRNA was detected by RT-PCR and A20 protein expression by immunoblotting. RNA was isolated and A20 or $\beta$-actin (control) mRNA was amplified by RT-PCR. Protein expression was analysed by immunoprecipiptation ( $\alpha$-A20) and/or immunoblot staining ( $\alpha$-Src, $\alpha$-PKD).
A

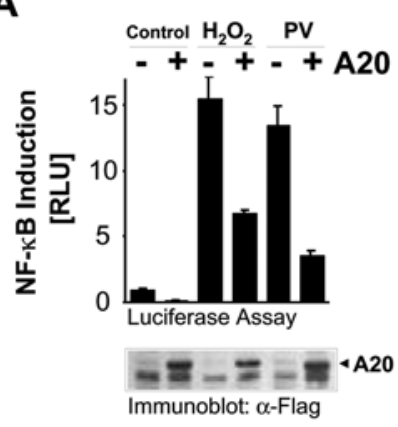

C

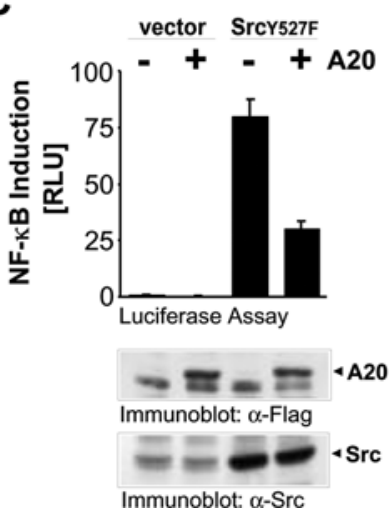

B

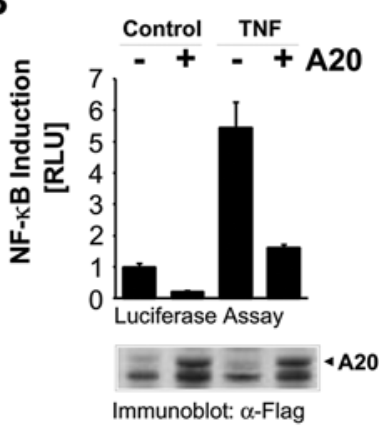

D

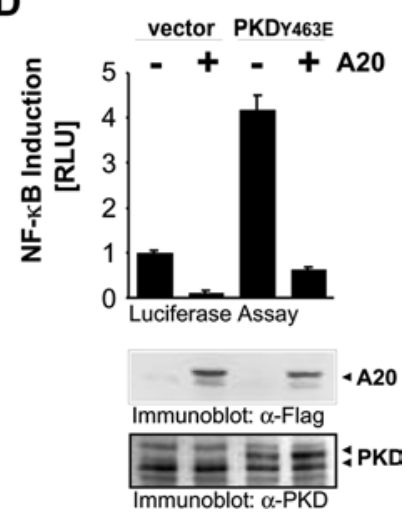

Figure 6 A20 expression inhibits oxidative-stress-dependent NF- $\kappa$ B activation

(A)-(D) HeLa cells were transfected with NF- $\kappa$ B and $\beta$-gal reporter genes and vector control or A20. Cells were treated with pervanadate (PV, $5 \mu \mathrm{M}), \mathrm{H}_{2} \mathrm{O}_{2}(500 \mathrm{nM})$ or TNF- $\alpha(50 \mathrm{ng} / \mathrm{ml})$ for $16 \mathrm{~h}$, or co-transfected with active PKD (PKD.Y463E) or active Src (Src.Y527F). Luciferase and $\beta$-gal reporter gene assays were performed. Protein expression was controlled by immunoblotting against indicated proteins with anti-FLAG ( $\alpha$-Flag; A20), anti-Src $(\alpha-\operatorname{Src})$ and anti-PKD $(\alpha-P K D)$. Results are means \pm S.D. RLU, relative light units. 

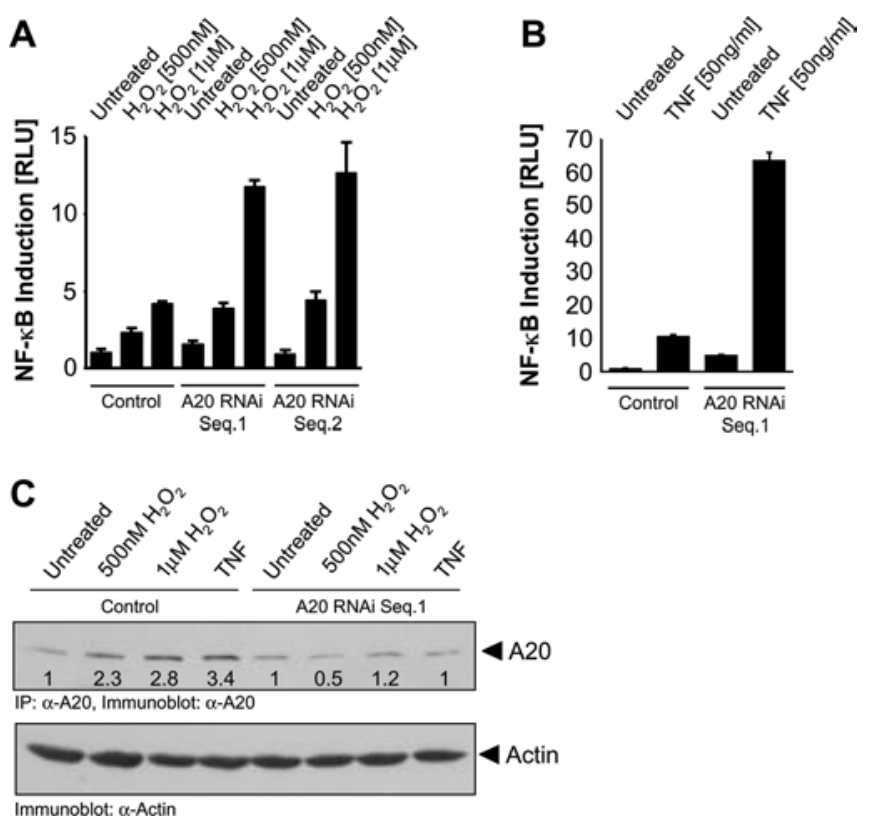

Figure 7 Silencing of A20 expression enhances oxidative-stress-mediated $\mathrm{NF}-\boldsymbol{K}$ B induction

(A) and (B) HeLa cells stably expressing the NF- $\kappa$ B luciferase and $\beta$-gal reporters were transfected for $48 \mathrm{~h}$ with vector control (pSuper) or A20 RNAi (pSuper.A20 RNAi Seq.1 or Seq.2), treated with $\mathrm{H}_{2} \mathrm{O}_{2}$ or TNF- $\alpha$ as indicated (16 h), and luciferase reporter gene assays were performed. Results are means \pm S.D. (C) A20 protein expression under the experimental conditions described in (A) and (B) was analysed by immunoprecipitation followed by immunoblotting $(\alpha-$ A20). Numbers indicate the increase of A20 levels relative to untreated control cells. Actin expression was monitored by immunoblot staining ( $\alpha$-actin) and served as a standard.

Control

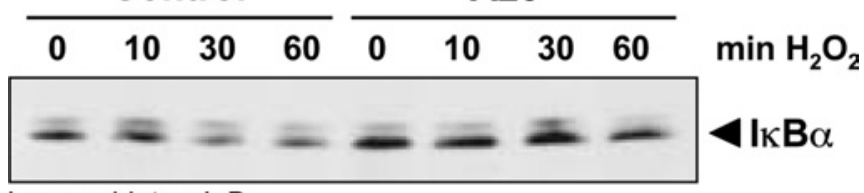

Immunoblot: $\alpha-\mid \kappa \mathrm{B} \alpha$

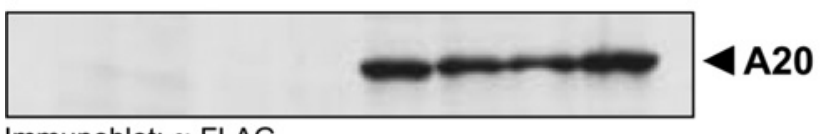

Immunoblot: $\alpha$-FLAG

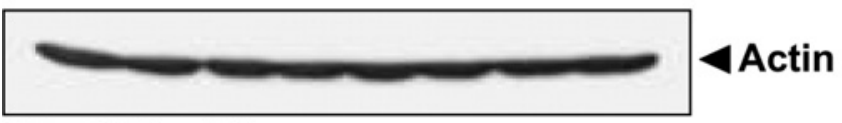

Immunoblot: $\alpha$-Actin

\section{Figure 8 A20 expression blocks $I_{\kappa} B \alpha$ degradation}

FLAG-tagged A20 or vector control was overexpressed in HeLa cells. Cells were treated with $\mathrm{H}_{2} \mathrm{O}_{2}$. Lysates were separated by SDS/PAGE ( $10 \%$ gels), and $\mathrm{I}_{\kappa} \mathrm{B} \alpha$ degradation was monitored by immunoblotting with $\alpha-I_{\kappa} \mathrm{B} \alpha$. A20 expression was analysed with $\alpha$-FLAG. Staining of actin $(\alpha$-Actin) served as a loading control.

cells to additional bursts of oxidative stress does not permit the activation of NF- $\kappa$ B and the subsequent survival response.

\section{DISCUSSION}

Oxidative stress promotes cell death and can induce gene transcription, but not much is known concerning the signalling cas- cades which exert these biological functions [4]. One transcription factor that is well known to control oxidative-stress-mediated gene regulation is $\mathrm{NF}-\kappa \mathrm{B}[2,6,25]$. It has been demonstrated that $\mathrm{NF}-\kappa \mathrm{B}$ can promote pro-survival signalling, and can also induce both anti-apoptotic and anti-necrotic genes [11]. One of the genes induced by NF- $\kappa \mathrm{B}$ in response to many stimuli is the zinc-finger protein A20, which, in TNF- $\alpha$ signalling, can protect cells from apoptosis $[13,14]$.

By comparing A20 levels in several human cell lines, we found that cells such as the human breast carcinoma cell line MDA-MB435 , which express high levels of A20 mRNA and protein, were more sensitive to oxidative-stress-mediated cell death compared with cells with lower levels of A20, such as HeLa cells (Figure 1). Consequently, depleting A20 levels with RNAi in MDA-MB-435 cells significantly decreased their sensitivity to $\mathrm{H}_{2} \mathrm{O}_{2}$ (Figure 1C). To investigate further the role of A20 in oxidative-stress-induced cell death, we then compared oxidative-stress- and TNF- $\alpha$-mediated cell death in cells either overexpressing or depleted in A20 (Figure 2). Again, despite its anti-apoptotic function in cytokine signalling, A20 actually enhanced death mediated by oxidative stress.

How can A20 be protective in cytokine signalling, but promote cell death in oxidative stress signalling? HeLa cells exposed to TNF- $\alpha$ undergo apoptosis, whereas, in response to oxidative stress, they undergo death by necrosis (Figure 3 ). Thus the proposed anti-apoptotic function of A20 has no effect on cells exposed to oxidative stress. Moreover, A20 can also function as an inhibitor of NF- $\kappa \mathrm{B}$ (Figures 6 and 7). In this regard, it is worth noting that NF- $\kappa \mathrm{B}$ activation in response to $\mathrm{c}-\mathrm{Myc}$-and TNF- $\alpha$ leads to the up-regulation of MnSOD (manganese superoxide dismutase) which eliminates ROS [28]. It is therefore tempting to speculate that $\mathrm{NF}-\kappa \mathrm{B}$-dependent gene products protect cells from $\mathrm{H}_{2} \mathrm{O}_{2}$-induced responses, and that A20 would block this, effectively leading to death by necrosis. The exposure of HeLa cells to oxidative stress leads to NF- $\kappa \mathrm{B}$ activation and cell survival [5]. Blocking the induction of NF- $\kappa \mathrm{B}$ by a super-dominant $\mathrm{I} \kappa \mathrm{B} \alpha$ mutant led to an increase in cell death in response to increasing concentrations of oxidative stress, when compared with control cells (Figure 4). This shows that by blocking the induction of $\mathrm{NF}-\kappa \mathrm{B}$ and by blunting cellular survival, A20 has a pro-necrotic function in oxidative stress signalling.

Previous studies have shown that A20 expression is regulated by NF- $\kappa$ B and that A20 can block activation of NF- $\kappa$ B through a negative-feedback loop [15,20,21]. Treatment of HeLa cells either with $\mathrm{H}_{2} \mathrm{O}_{2}$ or with compounds which elevate intracellular ROS, such as BSO induced A20 mRNA and protein comparable with the positive control TNF- $\alpha$ (Figure 5). We and others recently described that the oxidative-stress-mediated NF- $\kappa$ B activation and cellular survival in HeLa cells requires the tyrosine kinase Src and the serine/threonine kinase PKD [5,24,25]. A20 mRNA and protein levels were also up-regulated by expression of active alleles of these proteins, indicating that A20 expression is regulated by this signalling pathway.

To determine whether A20 can inhibit the oxidative-stressmediated NF- $\kappa$ B activation pathway, we measured the ability of HeLa cells transfected with A20 to induce NF- $\kappa$ B in response to $\mathrm{H}_{2} \mathrm{O}_{2}$. NF- $\kappa$ B transcriptional activity induced by $\mathrm{H}_{2} \mathrm{O}_{2}$, pervanadate, TNF- $\alpha$, activated Src (Src.Y527F) and activated PKD (PKD.Y463E) was significantly blunted in cells that were transiently transfected with A20 (Figure 6). This suggests that the induction of A20 by oxidative stress does indeed initiate a negative-feedback loop which blocks NF- $\kappa$ B. This was confirmed using A20 RNAi, which significantly increased NF- $\kappa$ B reporter activity in cells exposed to oxidative stress or TNF- $\alpha$ (Figure 7). Moreover, the high expression of A20 in MDA-MB-435 cells 
A

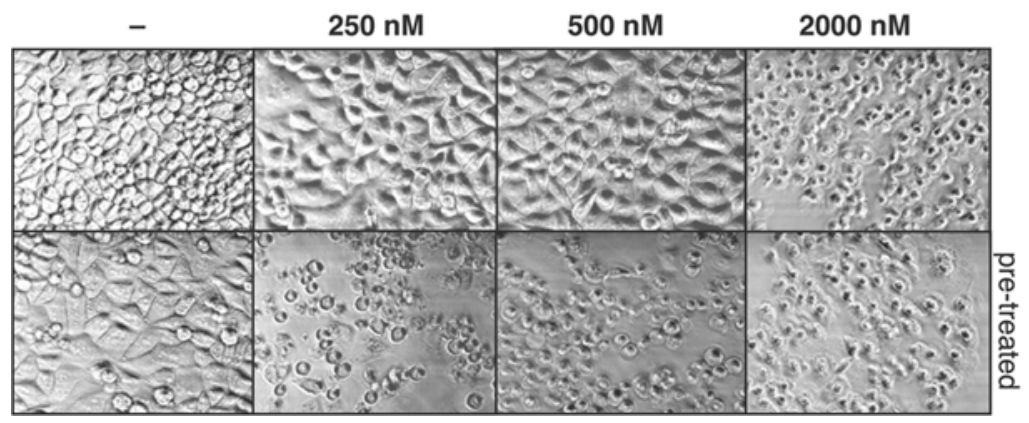

B

$\mathrm{H}_{2} \mathrm{O}_{2}$

Control

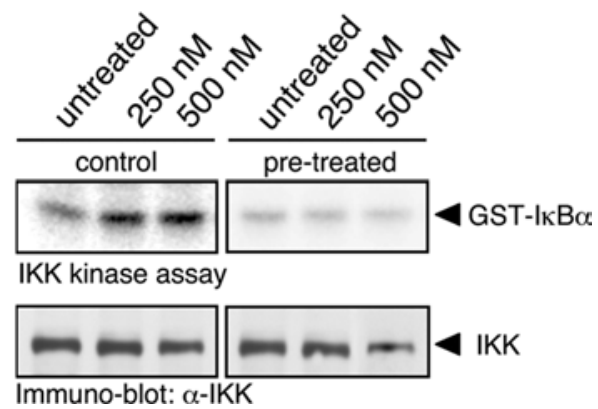

Figure 9 ROS-sensitized cells lack NF- $\kappa$ B activation

(A) HeLa cells were pre-treated with $500 \mathrm{nM} \mathrm{H}_{2} \mathrm{O}_{2}$ (lower panels) or left untreated (upper panels). After $8 \mathrm{~h}$, cells were washed and culture medium was replaced. Cells then were treated with the indicated concentrations of $\mathrm{H}_{2} \mathrm{O}_{2}$ for $16 \mathrm{~h}$, and photographed (phase-contrast, $10 \times$ ). (B) HeLa cells were pre-treated with $500 \mathrm{nM} \mathrm{H}_{2} \mathrm{O}_{2}$ or left untreated (control). After $8 \mathrm{~h}$, cells were washed and treated with the indicated concentrations of $\mathrm{H}_{2} \mathrm{O}_{2}$ for $10 \mathrm{~min}$. IKK $\gamma$ was immunoprecipitated, and an IKK assay was performed using GST-IKB$\alpha$ as substrate (upper panel). Expression of IKK was determined by immunoblotting with anti-IKK $\alpha / \beta$ antibody (lower panel).

correlated with the lack of $\mathrm{NF}-\kappa \mathrm{B}$ activation in response to oxidative stress [5], whereas HeLa cells responded to oxidative stress by inducing NF- $\kappa \mathrm{B}$ (Figure $5 \mathrm{~A})$. These data suggest that, by regulating the levels of $\mathrm{A} 20, \mathrm{NF}-\kappa \mathrm{B}$ controls the balance between necrotic cell death and cellular survival in response to oxidative stress.

The data thus far are consistent with a model in which high levels of A20 predispose cells to oxidative-stress-induced death. Since NF- $\kappa$ B induces A20 expression in $\mathrm{H}_{2} \mathrm{O}_{2}$-treated cells (Figures 2 and 5), which then in a negative-feedback loop blocks $\mathrm{NF}-\kappa \mathrm{B}$ (Figure 6), cells with already high basal levels of A20 should be sensitized to necrotic cell death. To test this model, we pre-treated HeLa cells with a low dose of $\mathrm{H}_{2} \mathrm{O}_{2}$ to induce NF- $\kappa$ B and $\mathrm{A} 20$, but not cell death, allowed them to recover, and then re-exposed them to increasing concentrations of $\mathrm{H}_{2} \mathrm{O}_{2}$. Consistent with our model, under these conditions, cells were significantly more sensitized to $\mathrm{H}_{2} \mathrm{O}_{2}$-induced death when compared with control untreated cells (Figure 8). As a control, we also showed that these cells had a blunted $\mathrm{NF}-\kappa \mathrm{B}$ response, as measured in IKK assays. Conversely, control cells which were not pre-treated with $\mathrm{H}_{2} \mathrm{O}_{2}$ showed a normal IKK response. These data show that the induction of A20 observed in response to $\mathrm{H}_{2} \mathrm{O}_{2}$ blocks NF- $\kappa$ B such that the re-exposure of cells to additional bursts of oxidative stress does not permit the activation of $\mathrm{NF}-\kappa \mathrm{B}$ and a survival response.

The precise mechanism by which A20 blocks activation of NF$\kappa \mathrm{B}$ remains to be defined. A20 has been shown to inhibit TNF- $\alpha$ and IL-1-stimulated NF- $\kappa \mathrm{B}$ activation by binding to TRAF (TNF-receptor-associated factor) 2 and 6 , and by disrupting the recruitment of death domain signalling proteins [29,30]. However, in $\mathrm{HeLa}$ cells, oxidative-stress-dependent NF- $\kappa \mathrm{B}$ activation is mediated by a distinct signalling cascade independent of TRAF2 or TRAF6, which converges at the level of the I $\kappa$ B-IKK signalling complex $[5,26,27]$. A20 blocks NF- $\kappa$ B activation mediated by a constitutively active PKD allele (PKD.Y463E), suggesting that A20 functions either downstream, or at the same level, as PKD (Figure 6D). Therefore it is more likely that A20 inhibits the NF$\kappa \mathrm{B}$ activation pathway by interacting with the $\mathrm{I} \kappa \mathrm{B}-\mathrm{IKK}$ complex by binding to IKK $\alpha$ and IKK $\gamma[31,32]$ and/or by blocking $\mathrm{I} \kappa \mathrm{B} \alpha$ degradation. Although in response to oxidative stress, PKD is associated with the IKK complex [5], co-expression of PKD with A20 did not block the ability of PKD to translocate to IKK in $\mathrm{H}_{2} \mathrm{O}_{2}$-stimulated cells (results not shown). However, overex- pression of $\mathrm{A} 20$ did block the degradation of $\mathrm{I} \kappa \mathrm{B} \alpha$ in response to oxidative stress (Figure 8). In this context, A20 has recently been described to have target-specific de-ubiquitinating and ubiquitin ligase activities [33,34]. It was shown for TNF signalling that A20 terminates $\mathrm{NF}-\kappa \mathrm{B}$ signalling by polyubiquitinating RIP (receptor interacting protein) with its ubiquitin ligase domain [35]. Another possible mechanism in oxidative stress signalling would be that $\mathrm{A} 20$ de-ubiquitinates $\mathrm{I} \kappa \mathrm{B} \alpha$ and thus blocks its degradation. However, we did not notice changes in $\mathrm{I} \kappa \mathrm{B} \alpha$ ubiquitination in response to oxidative stress (results not shown), and therefore the exact mechanism by which $\mathrm{A} 20$ regulates $\mathrm{NF}-\kappa \mathrm{B}$ remains elusive. One possibility is the interaction of A20 with ABINs (A20binding inhibitors of $\mathrm{NF}-\kappa \mathrm{B})$, which were recently described as inhibitors of NF- $\kappa \mathrm{B}[36]$.

In summary, we have investigated the role of A20 in oxidativestress-mediated cell death. Our data reveal a novel role for A20 in sensitizing cells to oxidative stress in an NF- $\kappa$ B-dependent manner. Expression of A20 induced by ROS promotes a negativefeedback loop which blunts NF- $\kappa$ B activation. The net effect is a reduction of cellular survival, leading to cell death by necrosis, a function which is distinct from its anti-apoptotic role in cytokine signalling. Therefore we propose that A20 blocks NF- $\kappa \mathrm{B}$, thus sensitizing cells to oxidative-stress-induced death by necrosis. In this model, the levels of A20 define the sensitivity of cells to ROSinduced cell death. This may also help to explain why some cell types respond to ROS by induction of NF- $\kappa$ B-dependent survival, whereas, paradoxically, under identical conditions, other cells do not show a significant NF- $\kappa$ B response.

We thank T. Maniatis, V. Dixit and B. Schaffhausen for generously providing expression plasmids, C. Vincenz for providing an anti-A20 antibody, H. Wajant for providing human recombinant TNF- $\alpha$, M. Yoeli-Lerner for the RT-PCR protocol and L. Choi for excellent technical assistance. This work was supported by grants from the National Institutes of Health [CA 75134 (A. T.) and DK 63275 (C. F.)], from the Deutsche Forschungsgemeinschaft [ST0 439/1-1 (P.S.)] and from the Juvenile Diabetes Research Foundation International [CDA 2-2000-719 (S. T.G.)].

\section{REFERENCES}

1 Engelhardt, J. F. (1999) Redox-mediated gene therapies for environmental injury: approaches and concepts. Antioxid. Redox Signal. 1, 5-27

$2 \mathrm{Li}, \mathrm{N}$. and Karin, M. (1999) Is NF- $\kappa$ B the sensor of oxidative stress? FASEB J. 13, 1137-1143 
3 Kops, G. J., Dansen, T. B., Polderman, P. E., Saarloos, I., Wirtz, K. W., Coffer, P. J., Huang, T. T., Bos, J. L., Medema, R. H. and Burgering, B. M. (2002) Forkhead transcription factor F0X03a protects quiescent cells from oxidative stress. Nature (London) 419, 316-321

4 Finkel, T. (2003) Oxidant signals and oxidative stress. Curr. Opin. Cell Biol. 15, 247-254

5 Storz, P. and Toker, A. (2003) Protein kinase D mediates a stress-induced NF- $\kappa$ B activation and survival pathway. EMBO J. 22, 109-120

6 Fan, C., Li, Q., Ross, D. and Engelhardt, J. F. (2003) Tyrosine phosphorylation of $\left.\right|_{\kappa} B \alpha$ activates $\mathrm{NF}_{\kappa} \mathrm{B}$ through a redox-regulated and c-Src-dependent mechanism following hypoxia/reoxygenation. J. Biol. Chem. 278, 2072-2080

7 Mercurio, F. and Manning, A. M. (1999) NF- $\kappa$ B as a primary regulator of the stress response. Oncogene 18, 6163-6171

8 Storz, P., Doppler, H. and Toker, A. (2004) Protein kinase $C \delta$ selectively regulates protein kinase D-dependent activation of NF- $\kappa$ B in oxidative stress signaling. Mol. Cell. Biol. 24, 2614-2626

9 Schoonbroodt, S., Ferreira, V., Best-Belpomme, M., Boelaert, J. R., Legrand-Poels, S., Korner, M. and Piette, J. (2000) Crucial role of the amino-terminal tyrosine residue 42 and the carboxyl-terminal PEST domain of $\mathrm{I}_{\kappa} \mathrm{B} \alpha$ in NF- $\kappa \mathrm{B}$ activation by an oxidative stress. J. Immunol. 164, 4292-4300

10 Malewicz, M., Zeller, N., Yilmaz, Z. B. and Weih, F. (2003) NF $\kappa$ B controls the balance between Fas and tumor necrosis factor cell death pathways during $T$ cell receptorinduced apoptosis via the expression of its target gene A20. J. Biol. Chem. 278 32825-32833

11 Baichwal, V. R. and Baeuerle, P. A. (1997) Activate NF- $\kappa$ B or die? Curr. Biol. 7, R94-R96

12 Jaattela, M., Mouritzen, H., Elling, F. and Bastholm, L. (1996) A20 zinc finger protein inhibits TNF and IL-1 signaling. J. Immunol. 156, 1166-1173

13 Opipari, Jr, A. W., Hu, H. M., Yabkowitz, R. and Dixit, V. M. (1992) The A20 zinc finger protein protects cells from tumor necrosis factor cytotoxicity. J. Biol. Chem. 267, 12424-12427

14 Lee, E. G., Boone, D. L., Chai, S., Libby, S. L., Chien, M., Lodolce, J. P. and Ma, A. (2000) Failure to regulate TNF-induced NF- $\kappa$ B and cell death responses in A20-deficient mice. Science 289, 2350-2354

15 Beyaert, R., Heyninck, K. and Van Huffel, S. (2000) A20 and A20-binding proteins as cellular inhibitors of nuclear factor- $\kappa$ B-dependent gene expression and apoptosis. Biochem. Pharmacol. 60, 1143-1151

16 Laherty, C. D., Perkins, N. D. and Dixit, V. M. (1993) Human T cell leukemia virus type I Tax and phorbol 12-myristate 13-acetate induce expression of the A20 zinc finger protein by distinct mechanisms involving nuclear factor $\kappa$ B. J. Biol. Chem. 268, 5032-5039

17 Brummelkamp, T. R., Bernards, R. and Agami, R. (2002) A system for stable expression of short interfering RNAs in mammalian cells. Science 296, 550-553

18 Grell, M., Douni, E., Wajant, H., Lohden, M., Clauss, M., Maxeiner, B., Georgopoulos, S., Lesslauer, W., Kollias, G., Pfizenmaier, K. et al. (1995) The transmembrane form of tumor necrosis factor is the prime activating ligand of the $80 \mathrm{kDa}$ tumor necrosis factor receptor. Cell 83, 793-802

19 Weingartner, M., Siegmund, D., Schlecht, U., Fotin-Mleczek, M., Scheurich, P. and Wajant, $H$. (2002) Endogenous membrane tumor necrosis factor (TNF) is a potent amplifier of TNF receptor 1-mediated apoptosis. J. Biol. Chem. 277, 34853-34859

Received 23 August 2004/26 October 2004; accepted 4 November 2004

Published as BJ Immediate Publication 4 November 2004, D0I 10.1042/BJ20041443
20 Grey, S. T., Arvelo, M. B., Hasenkamp, W., Bach, F. H. and Ferran, C. (1999) A20 inhibits cytokine-induced apoptosis and nuclear factor $\kappa \mathrm{B}$-dependent gene activation in islets. J. Exp. Med. 190, 1135-1146

21 Cooper, J. T., Stroka, D. M., Brostjan, C., Palmetshofer, A., Bach, F. H. and Ferran, C. (1996) A20 blocks endothelial cell activation through a NF- $\kappa$ B-dependent mechanism. J. Biol. Chem. 271, 18068-18073

22 Meister, A. (1983) Selective modification of glutathione metabolism. Science 220 472-477

23 Georgiou, G. (2002) How to flip the (redox) switch. Cell 111, 607-610

24 Storz, P., Doppler, H., Johannes, F. J. and Toker, A. (2003) Tyrosine phosphorylation of protein kinase $\mathrm{D}$ in the pleckstrin homology domain leads to activation. J. Biol. Chem. 278, 17969-17976

25 Storz, P. and Toker, A. (2003) NF- $\kappa$ B signaling - an alternate pathway for oxidative stress responses. Cell Cycle 2, 9-10

26 Karin, M. (1999) How NF- $\kappa$ B is activated: the role of the $l_{\kappa} B$ kinase (IKK) complex. Oncogene 18, 6867-6874

27 Israel, A. (2000) The IKK complex: an integrator of all signals that activate NF- $\kappa$ B? Trends Cell Biol. 10, 129-133

28 Tanaka, H., Matsumura, I., Ezoe, S., Satoh, Y., Sakamaki, T., Albanese, C., Machii, T., Pestell, R. G. and Kanakura, Y. (2002) E2F1 and c-Myc potentiate apoptosis through inhibition of NF- $\kappa$ B activity that facilitates MnSOD-mediated ROS elimination. Mol. Cell 9. 1017-1029

29 Heyninck, K., De Valck, D., Vanden Berghe, W., Van Criekinge, W., Contreras, R., Fiers, W., Haegeman, G. and Beyaert, R. (1999) The zinc finger protein A20 inhibits TNF-induced NF- $\kappa$ B-dependent gene expression by interfering with an RIP- or TRAF2-mediated transactivation signal and directly binds to a novel NF- $\kappa$ B- inhibiting protein ABIN. J. Cell Biol. 145, 1471-1482

30 He, K. L. and Ting, A. T. (2002) A20 inhibits tumor necrosis factor (TNF) $\alpha$-induced apoptosis by disrupting recruitment of TRADD and RIP to the TNF receptor 1 complex in Jurkat T cells. Mol. Cell. Biol. 22, 6034-6045

31 Zetoune, F. S., Murthy, A. R., Shao, Z., Hlaing, T., Zeidler, M. G., Li, Y. and Vincenz, C. (2001) A20 inhibits NF- $\kappa$ B activation downstream of multiple Map3 kinases and interacts with the $I_{\kappa}$ B signalosome. Cytokine $\mathbf{1 5}, 282-298$

32 Zhang, S. Q., Kovalenko, A., Cantarella, G. and Wallach, D. (2000) Recruitment of the IKK signalosome to the p55 TNF receptor: RIP and A20 bind to NEMO (IKK $\gamma$ ) upon receptor stimulation. Immunity 12, 301-311

33 Evans, P. C., Smith, T. S., Lai, M. J., Williams, M. G., Burke, D. F., Heyninck, K., Kreike, M. M., Beyaert, R., Blundell, T. L. and Kilshaw, P. J. (2003) A novel type of deubiquitinating enzyme. J. Biol. Chem. 278, 23180-23186

34 Evans, P. C., Ovaa, H., Hamon, M., Kilshaw, P. J., Hamm, S., Bauer, S., Ploegh, H. L. and Smith, T. S. (2004) Zinc-finger protein A20, a regulator of inflammation and cell survival, has de-ubiquitinating activity. Biochem. J. 378, 727-734

35 Wertz, I. E., O'Rourke, K. M., Zhou, H., Eby, M., Aravind, L., Seshagiri, S., Wu, P., Wiesmann, C., Baker, R., Boone, D. L. et al. (2004) De-ubiquitination and ubiquitin ligase domains of $A 20$ downregulate NF- $\kappa$ B signalling. Nature (London) 430, 694-699

36 Heyninck, K., Kreike, M. M. and Beyaert, R. (2003) Structure-function analysis of the A20-binding inhibitor of NF- $\kappa$ B activation, ABIN-1. FEBS Lett. 536, 135-140 